\title{
ETIKA BISNIS ISLAM: SEBUAH KAJIAN KOMPARATIF
}

\author{
Disfa Lidian Handayani \\ Fakultas Ekonomi dan Bisnis Islam UIN Raden Fatah Palembang \\ e-mail: disfalidian_uin@radenfatah.ac.id
}

\begin{abstract}
Abstrak: A norm or ethics is a reflection of the underlying philosophical values. Capitalist economic system, for example, has philosophical values which depart from Protestant ethics thought developed by Calvin (Calvinism). Islamic economics, regardless of the debate whether it is included in science that stands alone or is part of the current economic system, requires a strong foundation of philosophical thought. Since the 1970s, research studies of Islamic Economics have been studied increasingly by Islamic economic scholars. Along with the development of Islamic Economics, the idea arises about how to do business in an Islamic way. To keep the business carried out with Islamic teachings, a series of moral rules and Islamic Business Ethics are needed. This paper aims to explain the concept of Islamic business ethics starting from the philosophical foundation to the practice of business behavior in the field. In addition, this paper also compares Islamic business ethics with various other business ethics concepts such as Protestant \& Judeo-cristian business ethics, Buddhist business ethics, and Hindu business ethics.
\end{abstract}

Keyword: Etika Bisnis, Prilaku Bisnis, Islam, Hindu, Budhha, Judeo-Cristian, Protestan, filsafat, Ekonomi Islam.

\section{PENDAHULUAN}

Perkembangan praktek bisnis di masa modern ini membutuhkan sebuah perangkat moral untuk mendukung seseorang dalam memutuskan keputusan bisnis yang beretika. Perangkat moral berupa etika tersebut menuntun seseorang untuk menentukan keputusan bisnis mana yang akan digunakan dari sekian banyak keputusan bisnis yang tersedia. Contohnya seperti keputusan bisnis apa yang akan diambil seseorang atau perusahaan jika dihadapkan pada dilema menggunakan sogokan atau tidak, ketika Ia dihadapkan pada lingkungan yang terbiasa berbuat 
demikian untuk melancarkan bisnis. mempengaruhi perekonomian dunia karena Pembahasan dalam kajian etika akan dapat seluruh bank sentral diseluruh dunia menjawab apakah tindakan seseorang atau perusahaan tersebut sesuai dengan etika atau tidak.

Perhatian terhadap etika menjadi semakin intens semenjak kasus Enron mencuat kepermukaan yang diungkap oleh whistle blower atau stakeholder perusahaan yang memberikan informasi mengenai prilaku yang tidak terpuji dari perusahaan tersebut. Para petinggi Enron menyalahgunakan wewenang dan kekuasaan dalam memanipulasi data keuangan sehingga laporan keuangan perusahaan tersebut tampak sehat padahal kenyataannya berkebalikan. ${ }^{1}$ Kemudian adapula kasus Bank Barclays yang menarik perhatian dunia pada Juni 2012. Bank ini dinyatakan melakukan manipulasi London Interbank Offered Rate (LIBOR) pada pasar keuangan internasional. Bank Barclays melakukan trik-trik dengan mengirimkan SMS serta email kepada para trader untuk memanipulasi tingkat LIBOR padahal seharusnya tingkat LIBOR hanya boleh ditentukan oleh mekanisme pasar. ${ }^{2}$ Manipulasi pada LIBOR ini sangat

\footnotetext{
${ }^{1}$ Craig Johnson, “Enron's Ethical Collapse: Lessons for Leadership Educator", dalam Journal of Leadership Education, Vol. 2, Issue 1, (2003), hlm.45-56.

${ }^{2}$ Darrell Duffie dan Jeremy C. Stein, "Reforming LIBOR and Other Finansial Market Benchmarks", dalam Journal of Economic Perspective, Vol. 29, No.2, (2015), hlm. 191-212.
}

Indonesia juga terjadi kasus yang membuat kita mempertanyakan kembali masalah etika bisnis. Salah satunya adalah kasus Bantuan Likuiditas Bank Indonesia (BLBI) pada tahun 1998 yaitu adanya penyimpangan penyaluran bantuan tidak wajar. Dari Rp 144,536 triliun, yang disalahgunakan oleh bankir dan oknumoknum yang tidak bertanggung jawab adalah senilai $\mathrm{Rp} 138,442$ triliun atau sekitar $95,5 \%$. $^{3}$

Etika bisnis dipelajari bukan hanya untuk mengetahui tentang apa itu etika bisnis, namun lebih penting lagi, etika bisnis bertujuan untuk membantu para pebisnis memutuskan keputusan bisnis yang beretika. Etika bisnis diharapkan dapat menjaga seseorang untuk tidak berbisnis yang unethical seperti contohcontoh kasus diatas. Ilmu etika memiliki sejarah yang panjang. Pengenalan ilmu etika telah dikenal sejak masa Yunani kuno dengan konsep ethos-nya. Pengertian dan perkembangan etika bisnis akan dijabarkan pada point 3 dalam paper ini. Dalam Islam juga dikenal kata yang memiliki makna yang dekat dengan kata 'etika' yaitu 'khuluk'. Penjabaran lebih rinci mengenai

${ }^{3}$ Nurhayani, "Upaya Penyelesaian BLBI (Bantuan Likuiditas Bank Indonesia)", dalam Lex Jurnalica, Vol.4, No.1, (2006), hlm. 30. 
konsep etika dalam bisnis Islam akan adakalanya juga sebagai sumber keteraturan dipaparkan pada point 7 dalam paper ini.

Etika sangat erat kaitannya dengan nilai-nilai masyarakat dan nilai agama yang dianut oleh masyarakat. Teori tentang hubungan masyarakat dan agama telah banyak dibahas oleh Durkheim dan Weber.

Durkheim menyatakan bahwa agama adalah sebuah perekat masyarakat yang membuat satu individu merasa dekat dengan individu lainnya. Durkheim mengartikan agama sebagai sebuah sistem kepercayaan dan praktik yang berhubungan dengan sesuatu yang suci (sacred), yang mempersatukan pemeluknya menjadi suatu komunitas moral yang tunggal. ${ }^{4}$ Dalam bukunya The Elementary Form of the Religious Life, Durkheim melakukan studi dengan mengambil sampel berdasarkan praktik-praktik relijius masyarakat Aborigin Australia yang kemudian ia identifikasikan sebagai suatu 'prinsip totemik'. Durkeim menjelaskan bahwa agama merupakan sumber keteraturan sosial dan moral, mengikat anggota masyarakat kedalam suatu proyek sosial bersama, sekumpulan nilai dan tujuan sosial bersama. ${ }^{5}$ Menurut perspektif Weberian, agama dapat menjadi sumber perubahan dan tantangan sosial, dan

\footnotetext{
${ }^{4}$ Rusli Karim, Agama dan Masyarakat Industri Modern, (Yogyakarta: Media Widya Mandala, 1992),

${ }^{5}$ Peter Connelly, Aneka Pendekatan Studi Agama, (Yogyakarta: Lkis Group, 2002), hlm. 1824.
} sosial dan legitimasi status quo. Dalam bukunya The Sosiology of Religion, ia membahas tentang interaksi agama dan organisasi sosial. Ia memberikan ulasan tentang makna relijius dan sistem etika dan keteraturan manusia, khususnya keteraturan ekonomis dan relasi pertukaran. ${ }^{6}$

Nilai-nilai yang dianut oleh masyarakat salah satunya adalah berasal dari nilai-nilai agama. Nilai-nilai tersebut mempengaruhi prilaku dan keputusan perbuatan dalam menjalani kehidupan, termasuk dalam kehidupan bisnis. Hal tersebut juga diungkapkan dalam penelitian Hunt dan Vittel bahwa agama (religion) mempengaruhi prilaku (behaviour) dan keputusan bisnis (action) seseorang atau sebuah organisasi bisnis. ${ }^{7}$ Nilai-nilai masyarakat ini berasimilasi, berevolusi dan beradaptasi terhadap perkembangan zaman dan kebutuhan masyarakat itu sendiri. Sehingga tidak jarang nilai-nilai yang semula menekankan sesuatu yang baik dan ideal, setelah mengalami perkembangan, malah berada jauh dari nilai semula yang ditetapkan; seperti contohnya apa yang terjadi pada etika protestan yang akhirnya melahirkan kapitalisme. Persinggungan antara nilai-nilai agama dengan kondisi

\footnotetext{
${ }^{6}$ Ibid., hlm. 280.

${ }^{7}$ Shelby D. Hunt dan Scott J Vittel, "The General Theory of Marketing Ethics: A Revision and Three Questions", dalam Journal of Macromarketing, Vol.26, (2006), hlm. 143-153.
} 
perkembangan saat ini, memerlukan aturan etika dalam melakukan bisnis yang beretika. Etika juga memiliki beragam pendekatan sistem etika. Masing-masing sistem etika pada akhirnya membuat tiap individu memiliki pemahaman yang berbeda tentang tujuan akhir dari kegiatan bisnis.

Paper ini akan menjelaskan mengenai beberapa etika bisnis seperti etika bisnis Islami, etika bisnis Protestan \& Judeocristian, etika bisnis Buddism, dan etika bisnis Hindu. Pendekatan yang digunakan adalah dengan pendekatan filosofi masingmasing agama yang mempengaruhi etika bisnis agama bersangkutan. Adapun cara yang ditempuh adalah dengan melihat sistem etika dan aksioma-aksioma yang digunakan oleh masing-masing etika tersebut. Pada akhirnya paper ini akan lebih banyak menjabarkan mengenai ekonomi Islam mulai dari filosofi dasar, konsep, tujuan, teori, Islamic worldview, body of knowladge serta metodologi. Setelah hal tersebut dibahas, kemudian dari nilai filosofi ekonomi Islam tersebut akan di'turun'kan/ dihasilkan sebuah etika bisnis yang sesuai dengan nilai-nilai Islam.

\section{KAJIAN TEORI}

\section{Etika Bisnis: Pengertian dan Perkembangan}

Etika dapat diartikan sebagai seperangkat prinsip moral yang membedakan antara yang benar dan yang salah. Etika adalah bagian dari ranah normatif yang menentukan apakah suatu tindakan seharusnya dilakukan atau tidak. ${ }^{8}$ Etika merupakan cabang dari filsafat. Dalam tradisi Barat, etika sering ditelusuri dari asal pemikiran filusuf Yunani kuno Socrates. Menurut Socrates, inti dari etika adalah untuk menjawab pertanyaan bagaimanakah kita seharusnya menjalani kehidupan. Domain etika adalah pada apa yang seharusnya orang lakukan. Sedangkan ilmu yang mempelajari mengenai apa yang orang lakukan pada kenyataan rillnya adalah domain ilmu-ilmu sosial seperti sosiologi, psikologi dan antropologi. Ilmu etika meminta kita untuk merenungkan kembali dan mengevaluasi nilai-nilai yang dipegang seseorang. ${ }^{9}$

Sedangkan etika bisnis adalah cabang etika yang meneliti aturan etika dan prinsipprinsip dalam konteks komersial; mempelajari berbagai masalah moral atau etika yang timbul dalam lingkungan bisnis; dan memberi penjelasan menganai kewajiban yang berlaku bagi setiap individu yang terlibat dalam

\footnotetext{
${ }^{8}$ Rafik Issa Beekun, Islamic Business Ethics, (Virginia: Internasional Institute of Islamic Thought, 1997), hlm.2.

${ }^{9}$ Joseph Desjardins, An Introduction to Business Ethics, (Singapore: Mc Graw Hill, 2014), hlm.
} 
perdagangan. Secara umum, etika bisnis adalah disiplin normatif, dimana standar etika tertentu dirumuskan dan kemudian diterapkan. Etika bisnis memberi penilaian mengenai apa yang harus dilakukan dan apa yang tidak harus dilakukan dalam bisnis. ${ }^{10}$ Istilah etika bisnis memiliki banyak padanan kata. Istilah etika bisnis dalam bahasa Inggris dikenal dengan istilah "business ethics". Tetapi dalam bahasa lain terdapat banyak variasi. Dalam bahasa Belanda pada umumnya dipakai nama "bedrijfsethiek" (etika perusahaan) dan dalam bahasa Jerman "unternehmensethik" (etika usaha). Didalam bahasa Inggris kadang-kadang dipakai juga istilah “corporate ethics" (etika korporasi).

Istilah-istilah itu berbeda diberbagai negara tergantung dari preferensi dan pada dasarnya semua nama itu menunjuk kepada studi tentang aspek-aspek moral dari berbagai kegiatan ekonomi dan bisnis. ${ }^{11}$

Dalam membangun suatu etika, termasuk etika bisnis, diperlukan suatu pendekatan dalam memahami etika tersebut. Ada banyak pendekatan yang dapat digunakan dalam merumuskan etika. Menurut Beekun, setidaknya ada enam sistem etika kontemporer yang kini

\footnotetext{
${ }^{10}$ Sabahuddin Azmi, "An Islamic Approach to Business Ethics", dalam Renaissance: A Monthly Islamic Journal Pakistan, Vol.15, Issue.5, (2005)

${ }^{11}$ K. Bertens, Pengantar Etika Bisnis, (Yogyakarta: Kanisius, 2000),
}

mendominasi tipologi pemikiran etis dunia, diantaranya: ${ }^{12}$

a. Relativisme

Relativisme merupakan sistem etika yang memandang tidak terdapat ukuran (kriteria) universal yang dapat digunakan untuk menentukan apakah sebuah tindakan itu etis atau tidak. Setiap orang memiliki kriteria etis yang berbeda-beda yang disebabkan oleh perbedaan latar belakang budayanya. Terdapat persoalan yang berkaitan dengan sistem etika ini yaitu mazhab relativisme ini bersifat self-centered yang hanya menitikberatkan pada individu dan mengenyampingkan pentingnya interaksi dengan dunia luar individu.

b. Utilitarianisme (kalkulasi untung rugi)

Pendekatan etika utilitarian sejak Cicero hingga Jeremy Benthem dan John Stuart Mill telah hidup selama hampir dua ribu tahun. Etika ini memandang bahwa nilai moral tindakan pribadi diukur hanya didasarkan oleh akibat atau konsekuansi dari tindakan tersebut. Suatu tindakan dinilai etik jika tindakan tersebut menghasilkan manfaat atau dampak menguntungkan bagi sebagian besar orang. Dengan

\footnotetext{
${ }^{12}$ Rafik Issa Beekun, Islamic Business
} Ethics...,hlm. 9-19. 
demikian, utilitarianisme sangat bersifat outcome oriented, karena menitikberatkan pada nilai akibat atau konsekuansi dari tindakan yang dilakukan. Banyak persoalan kritis yang dimunculkan oleh sistem etika utilitarianisme ini. Pertama, tidak jelas siapa yang menentukan atau merumuskan nilai apa yang 'baik' bagi sebagian besar orang? Kedua, aspirasi kaum minoritas yang tidak diterima. Ketiga, hak-hak dan tanggungjawab kolektif. Hal tersebut sangat bertentangan dengan ajaran Islam yang menjunjung tinggi hak dan tanggungjawab individu maupun kolektif. Keempat, utilitarianisme menentukan nilai hakikat etis tindakan dengan cara mengukur sejauh mana keuntungan atau manfaat (utilitas) yang akan diperoleh, serta sejauhmana tindakan tersebut dapat dilakukan (practicable).

c. Universalisme (kewajiban)

Kebalikan sistem utilitarianisme yaitu universalisme yang menitikberatkan pada maksud (tujuan) dari pada keputusan atau tindakan. Prinsip nilai yang mendasari mazhab universalisme adalah prinsip 'catagorical imperative' (kewajiban mutlak) dari Kant. Prinsip etis ini menekankan bahwa seseorang akan membuat keputusan dan bertindak sama dengan orang lain jika berada pada situasi yang sama. Jadi sistem ini menekankan pada kewajiban (duty) individu kepada individu lain dan martabat kemanusiaan (humanity). Persoalan yang muncul dari universalisme adalah konsep Kant tentang kewajiban (duty). Menurut Kant suatu tindakan dinilai etis jika tindakan tersebut dilakukan berdasarkan rasa kewajiban. Sebaliknya, suatu tindakan dipandang tidak etis atau tidak bermoral jika tindakan tersebut dilakukan berdasarkan pada perasaan atau kehendak diri (self-interest).

d. Hak (pemberian hak-hak individu)

Pendekatan hak (right) dalam sistem etika ini menekankan pada nilai tunggal (single value) yaitu kebebasan (liberty). Suatu keputusan dan tindakan dipandang etis ketika keputusan dan tindakan tersebut ditetapkan berdasarkan pada hak-hak individu yang menjamin kebebasan memilih (freedom of choice). Pendekatan ini meyakini bahwa setiap individu memiliki hak-hak moral (moral right) yang tidak dapat ditawar-tawar. Sebagai contoh, setiap warga Amerika secara legal dijamin hak-haknya: kebebasan, martabat, dan hak 
kebebasan memilih. Hak-hak ini pada gilirannya melahirkan 'mutual obligation' rasa kewajiban pada masing-masing diri individu. Dengan demikian, seorang pekerja berhak memperoleh imbalan (gaji) dan lingkungan kerja yang aman, sebaliknya majikan berhak memperoleh jaminan atas kerahasiaan bisnisnya dari para pekerjanya. Pendekatan etis berdasarkan hak ini dapat disalahartikan dan disalahgunakan. Pendekatan etis ini kerap digunakan oleh individu untuk lebih menuntut hak-haknya atas individu lain akhirnya seringkali terjadi ketidakmerataan pembagian hak. Selain itu pendekatan ini mengalami kesulitan untuk memberi batasan yang jelas akan hak-hak tersebut.

e. Keadilan distributif (kejujuran dan keadilan)

Pendekatan etika ini bertumpu pada nilai tunggal, yaitu keadilan (justice). Sesuatu dianggap etis jika suatu keputusan atau tindakan menjamin keadilan distribusi kekayaan, keuntungan, dan beban secara merata. Beberapa prinsip etis yang digunakan untuk menjamin distribusi keuntungan dan beban proporsional, diantaranya masing-masing pihak memperoleh bagian yang sama serta masing-masing pihak (individu) memperoleh bagian sesuai tingkat kebutuhan individu.

f. Hukum abadi/ eternal law yang bersumber pada kitab suci

Keputusan etis dalam sistem ini dibuat berdasarkan pada hukum abadi (eternal law) yang ditulis dalam Kitab Suci maupun dalam alam ciptaan Tuhan. Bagi banyak penulis, termasuk Thomas Aquinas, yakin bahwa dengan memahami bahwa dengan memahami Kitab Suci (maksudnya kitab injil) dan alam semesta, maka manusia akan memiliki kesadaran etis (ethical awareness) yang pada gilirannya membuat manusia tersebut akan bertindak secara etis.

\section{Etika Bisnis Protestant \& Judeo- cristian}

Pada awalnya, sikap yang diambil oleh gereja dalam rangka etika bisnis adalah penolakan terhadap hak milik pribadi serta kecurigaan yang sangat terhadap kekayaaan. Ajaran kristen tidak terlalu bersahabat terhadap dunia dagang dan bisnis maupun terhadap orang-orang yang bergerak dibidang bisnis. ${ }^{13}$ Dalam kitab suci Kristen terdapat cukup banyak teks yang bernada kritik terhadap kekayaan

${ }^{13}$ E.D. Putra, "Bisnis dan Etika Kristiani" dalam Jurnal Ulumul Quran, tanpa tahun, hlm.2229. 
dan uang, dalam Perjanjian Lama maupun Perjanjian Baru. Dalam seluruh Alkitab, orang kaya diminta membuka hatinya untuk kaum miskin, untuk janda, yatim piatu, dan untuk mereka malang dunianya. Dalam kalangan Kristen pada zaman kuno dan Abad Pertengahan, profesi pedagang sering dinilai kurang pantas. Dan karena itu urusan niaga banyak diserahkan kepada orang Yahudi, satu-satunya golongan bukan Kristen dalam masyarakat barat Abad Pertengahan. Agustinus (354-430) menegaskan bahwa "seorang pedagang barangkali bisa berkelakuan tanpa dosa, tapi tidak mungkin ia berkenan di hati Tuhan”. Dengan kata lain, pekerjaan seorang pedagang adalah netral dari sudut pandang moral namun tidak pernah bisa menjadi sesuatu yang sungguh baik. Profesi pedagang tidak pantas bagi orang Kristen. ${ }^{14}$

Pada abad-abad pertengahan, gereja mengeluarkan doktrin tentang harga yang adil (just price) dan upah adil. Menerima upah yang pantas sesuai dengan apa yang disumbangkan seseorang bagi kesejahteraan bersama dalam masyarakat. Pada saat itu dunia bisnis masih menempati urutan bawah, yang lebih pantas diwaspadai daripada dihargai. Karena terjadi keterkukungan yang dilakukan oleh gereja, maka timbulah pemberontakan di dalam hlm. masyarakat. Sikap gereja itulah yang melahirkan reformasi baru yang dirintis oleh Luther dan Calvin. Pemikiranpemikiran Luther dan Calvin ini membawa perkembangan dalam ekonomi kristen. Dalam doktrin Luther terdapat konsep 'panggilan' dan 'imamat orang percaya' telah memicu suatu perubahan sikap dan pandangan radikal terhadap dunia bisnis dan orang-orang yang bergerak dalam bidang tersebut. Dengan doktrin 'panggilan' maka orang dapat mengklaim bahwa jika ia berkecimpung didunia bisnis sebagai sebuah 'panggilan' (vocation) yang ditetapkan Allah. "Dunia melaksanakan kehendak Allah disana! Allah tidak hanya memanggil orang untuk menjadi pendeta, guru, atau tentara, tetapi juga untuk menjadi pengusaha". Pada masa tersebut doktrin ini dianggap sangat revolusioner. Kemudian dengan doktrin 'imamat orang percaya' membuat tidak ada sekat antara 'iman' dan 'awam', antara 'biara' dan 'dunia', dan antara 'doa' dan 'kerja'. Menjadi pedagang tidak lebih rendah daripada menjadi pendeta. Bekerja di dunia tidak lebih hina daripada bekerja dilingkungan biara. Dan akhirnya bekerja dipandang tidak kurang mulia daripada berdoa. $^{15}$

${ }^{15}$ E.D. Putra, "Bisnis dan Etika Kristiani" dalam Jurnal Ulumul Quran, tanpa tahun, hlm.2229. 
Ajaran Luther bahwa 'biara kita masyarakat sangat bangga akan adalah dunia ini' dikembangkan lebih lanjut kepemilikan benda (materialisme). Ajaran oleh Calvin dengan Calvinisme-nya, Calvin penting lainnya adalah tentang melalui sikap dan daya hidup yang oleh Weber disebut sebagai gaya hidup yang asketis terarah pada dunia (inner- worldly asceticm). Cirinya adalah sikap hidup yang disiplin, penuh tanggungjawab, hemat, rajin, dan produktif. Hidup didunia layaknya di biara. Pekerjaan dianggap ibadah. Ketika orang bekerja dengan disiplin dan penuh tanggungjawab, lalu hasilnya tidak dikonsumsi untuk kepemilikan modal dan konsep modal harus diputar. Konsep ini yang akhirnya memunculkan kapitalisme. Dampak dari ajaran untuk mengumpulkan modal dan memutar modal ini akhirnya menjadikan masyarakat yang dapat mengumpulkan material berupa uang dan modal tersebut menjadi individualis.

Pemikiran Calvin ini dapat bermewah-mewahan, melainkan selalu dipengaruhi oleh kondisi saat itu. Pada saat hidup hemat sehingga hal ini akan itu, sekitar abad 17 Masehi terjadi revolusi menimbulkan penumpukan kapital. Kapital tersebut diputarkan lagi pada usaha produktif sehingga menghasilkan kapital yang lebih banyak lagi. Weber dan Tawney melihat hubungan erat antara azas kerja seperti ini dengan pesatnya kegiatan bisnis dan ekonomi melalui kapitalisme. Mereka mengidentikkan etika Kristiani dengan kapitalisme. $^{16}$

Pemikiran dari pendeta Calvin ini telah melahirkan Kristen Protestan yang menyatakan bahwa bekerja adalah ibadah. Dengan asumsi dasar bahwa setiap manusia yang lahir membawa dosa dan untuk menebus dosa tersebut setiap manusia harus bekerja. Hal tersebut juga dikenal sebagai Protestant ethics. Dampaknya adalah

\footnotetext{
${ }^{16}$ Ibid., hlm. 22-29
} industri yang ditandai dengan ditemukannya teknologi berupa mesin uap oleh James Watt. Revolusi industri ini membuat perubahan didalam masyarakat dimana yang pada awalnya masyarakat menjual barang jika memiliki kelebihan, maka pada masa revolusi industri tersebut masyarakat sengaja mendirikan perusahaan untuk memproduksi barang. Terjadi perubahan dari family capitalism era menuju managerial capitalism era. Selain itu, ekonomi kapitasis yang memiliki dasar filosofis etika protestan ini semakin berkembang setelah sebagian dari masyarakat Eropa menjajah dan mendirikan koloni di Amerika serikat. Pada umumnya, masyarakat yang menganut ajaran protestant akan cenderung migrasi ke 
Amerika untuk mendapatkan kesejahteraan.

Prinsip kapitalisme tersebut sampai sekarang masih menjadi pedoman dasar di Amerika. Perlu ditekankan bahwa kapitalisme menggunakan sistem etika utilitarian yang berpendapat bahwa suatu tindakan dianggap baik apabila nilai manfaatnya lebih banyak. Suatu bisnis di anggap baik jika bisnis tersebut menguntungkan.

\section{Etika Bisnis Buddhism}

Buddha bukanlah agama, namun Buddha adalah ajaran mengenai cara menjalani kehidupan. Ada dua cabang utama dalam ajaran Buddha yaitu Hinayana dan Mahayana. Buddha Hinayana merupakan ajaran yang berakar dari kehidupan kehidupan Siddhartha Gautama, Sang Buddha. Buddha Hinayana dipraktekkan terutama di Thailand dan di daerah lain di Asia Tenggara. Sedangkan cabang Mahayana berkembang dari wilayah Tibet hingga ke Jepang. Cabang Mahayana menyebarkan prinsip-prinsip dan praktek Buddhis untuk khalayak yang lebih luas, karena mencoba untuk merancang sistem yang akan layak untuk setiap segmen dari populasi dan tidak akan terbatas pada biksu. Ada beberapa cabang lain dari dua cabang besar ini yaitu Zen, Buddhisme Tibet, dan Theravada. ${ }^{17}$

\footnotetext{
${ }^{17}$ Stefano Pace, "Does Religion Affect the Materialism of Consumers? An Emperical
}

Gould meneliti mengenai ajaran Buddha Mahayana yang banyak dianut oleh masyarakat Tibet. Dalam penelitiannya, Gould mengatakan bahwa Buddha Mahayana memberikan perhatian utama pada sifat kasih sayang untuk seluruh mahluk. Dalam ajaran Buddha, seluruh mahluk adalah ayah-ayah dan ibu-ibu kita. Dalam ajaran ini juga dikenal reinkarnasi yaitu sebuah pemahaman tentang setiap jiwa memiliki banyak kehidupan sebelum dan setelah kehidupan yang ia alami saat ini. ${ }^{18}$ Sehingga setiap manusia harus memperlakukan setiap makhluk dengan baik karena mungkin saja mereka adalah ayah, ibu atau saudara ketika di kelahiran lalu atau kelahiran mendatang.

Terdapat setidaknya empat doktrin dalam ajaran etika Buddha diantaranya: pertama kasih sayang (karuna), yang berarti bahwa seseorang dapat merasakan penderitaan orang lain seolah-olah ia yang mengalaminya. Kedua, cinta kasih (metta) yang berarti peduli dan mengurusi orang lain dengan berharap kebahagiaan bagi mereka. Ketiga, Sukacita empati (mudita) yaitu kemampuan untuk menemukan kebahagiaan dalam situasi apapun dan

Investigation of Buddist Ethics and the Resistance of the Self", dalam Journal of Business Ethics, Vol.112, No.1, (2013), hlm. 30.

${ }^{18}$ Stephen J. Gould, "The Buddist

Perspective on Business Ethics: Experiental Exercises for Exploration and Practice" dalam Journal of Business Ethics, Vol.14, No.1, (1995), hlm.63-70. 
mengekspresikan kebahagiaan untuk meningkatkan kebahagiaan orang lain. Dan Keempat, mudita yang artinya bahwa tidak ada sifat kepentingan pribadi maupun kecemburuan. ${ }^{19}$ Semua doktrin kebajikan yang dilakukan manusia di dunia tersebut bertujuan untuk mencapai nirvana. Adapun beberapa tahapan jalan menuju nirvana adalah: ${ }^{20}$

a. Hidup adalah penderitaan.

Segala keinginan di dunia ini dianggap sebagai sebuah penderitaan, termasuk diantaranya keingin memiliki sesuatu atau bersifat konsumerisme dan keingan untuk mengikuti gaya hidup.

b. Penyebab penderitaan adalah keinginan (desire).

Semakin tinggi keinginan maka semakin tinggi usaha yang harus diciptakan untuk memperolehnya. Jika keinginan akan sesuatu tidak terpenuhi maka tentu saja ini menyebabkan penderitaan. Misalnya keinginan mengkonsumsi barang. Ketika seseorang dapat mengkonsumsi pertama kali, maka hal yang dirasakannya adalah kebahagiaan. Kemudian akan timbul rasa tidak puas

\footnotetext{
${ }^{19}$ Stefano Pace, "Does Religion Affect the Materialism of Consumers? An Emperical Investigation of Buddist Ethics and the Resistance of the Self"..., hlm.35.

${ }^{20}$ Laszlo Zsolnai, "Western Economics Versus Buddhist Economics" dalam Society and Economy, Vol.29, No.2, (2007), hlm.145-153.
}

dan menginginkan hal yang lebih, dan jika tidak terpenuhi menyebabkan stress.

c. lenyapnya penderitaan adalah berhentinya keinginan.

Cara untuk menghentikan semua penderitaan didunia adalah menghilangkan keinginan.

d. Jalan menuju penghentian keinginan membutuhkan latihan.

Menghapus keinginan (desire) untuk mengatasi penderitaan harus dilakukan latihan terus menerus. Tujuan akhir dari langkah ini adalah untuk mencapai nirvana.

Kunci utama keselamatan dalam agama Buddha adalah menolak dunia materi dan berfokus pada kontemplasi. Di Budhha dikenal pula karma (perbuatan) baik dan karma buruk. Jika melakukan hal baik akan berdampak pada kehidupan yang akan datang. Kekayaan adalah tanda karma baik pada masa lalu. Jadi, menurut ajaran Budhha, kekayaan yang dimiliki seseorang saat ini bukan hasil jerih payahnya saat ini namun merupakan akumulasi dari perbuatan masa lalu. Jika seseorang dapat melakukan perbuatan baik dan menempuh empat langkah menuju nirvana, maka yang diharapkannya adalah tidak ada lagi kelahiran dimasa datang namun ia menuju nirvana. Untuk melakukan hal tersebut ia harus berbuat baik kepada sesama manusia 
dan mementingkan kepentingan masyarakat atas dirinya. Ia harus mengurangi konsumsi agar orang lain dapat menikmati konsumsi yang serupa pula. Manusia juga harus melakukan kegiatan yang bisa memberdayaakan masyarakat. ${ }^{21}$ Sehingga orang lain harus didahulukan. Seperti yang diungkapkan Barnhard bahwa ajaran Buddha pada dasarnya adalah variasi dari utilitarianisme. ${ }^{22}$ Ajaran Budhha sangat mementingkan azas kemanfaatan bersama dan 'mengorbankan' keinginan pribadi.

Salah satu negara yang menggunakan ajaran Budha yaitu Jepang. Negara ini mengkolaborasi beberapa ajaran seperti Konfusianisme dan Shintoisme yang menjadi filosofi dasar dari nilai etika bisnis yang mereka gunakan. Ekonomi Kapitalisme dan ajaran Buddha dapat saling berkolaborasi karena pada dasarnya kedua filosofinya berasal dari sistem filosofi utilitarianisme. Jepang tidak hanya dipengaruhi oleh Ekonomi Kapitalisme, namun Jepang mulai memberikan pengaruh dengan diterimanya Etika “Kyosei” didunia internasional dan dijadikan salah satu

${ }^{21}$ Stephen J. Gould, "The Buddist Perspective on Business Ethics: Experiental Exercises for Exploration and Practice" ..., hlm.6370 .

${ }^{22}$ Michael G. Barnhart, "Theory and Comparison in the Discussion of Buddhist Ethics" dalam Philosophy East and West, Vol.62, No.1, (2012), hlm. 16-43. prinsip etika melalui "The Caux Roundtable Principle for Business". ${ }^{23}$

Tidak hanya itu, negara China yang juga menganut ajaran Buddha dan juga melakukan asimilasi dengan ajaran Konfunsius. Dalam ajaran Konfunsius, manusia harus bersifat rasional dan realistis. Dalam bidang bisnis, masyarakat China juga menggunakan filsafat dari Tao Chu Kung dengan enam belas prinsip berbisnis dengan baiknya. Dalam prinsipprinsip ini, terdapat dua bagian dalam setiap itemnya yaitu (1) menunjukan yang positif dan (2) menunjukkan yang negatif yang dianggap sebagai petuah (warning). Gaya positif dan negatif ini disejajarkan dengan filsafat yin dan yang. Yang diasosiasikan dengan surga, semua positif, pria, cahaya, api, keras, sisi kanan, hidup dan bergerak. Sedangkan Yin dihubungkan dengan bumi, semua yang negatif, wanita, kegelapan, air, lunak, sejuk, sisi kiri, dan statis (deadly and still). Dari indikasi tersebut Yin dan Yang berlawanan. Namun mereka justru saling mengisi (complementary), dan perpaduan yang saling mendukung, serta dipelihara dengan keseimbangan dan harmoni. Filsafat ini sering digunakan dalam aktifitas bisnis. Contohnya adalah setiap pengambilan keputusan baik stategis maupun operasional

${ }^{23}$ A.A. Nugroho, Dari Etika Bisnis ke Etika Ekobisnis, (Jakarta: PT Grasindo, 2001) 
merupakan "interaksi antara otak rasional dan kepekaan moral etis". ${ }^{24}$

\section{Etika Bisnis Hindu}

Literatur yang membahas mengenai etika bisnis Hindu biasanya mengambil studi kasus di India. Hal ini disebabkan karena sekitar $85 \%$ penduduknya beragama Hindu. ${ }^{25}$ Hindu sebagai agama merupakan sebuah pandangan hidup dan cara hidup yang terkait panduan teoritis dan praktis didalam kehidupan spiritual. ${ }^{26}$ Agama Hindu mengenal banyak Dewa dan Dewi. Dewa-Dewi tersebut merupakan perlambangan dari kekuatan Alam. Manusia dapat memanfaatkan segala sesuatu di alam ini untuk kepentingan hidupnya. Namun, manusia harus berterimakasih dengan jalan memberikan karya terbaik berupa pekerjaan yang dilakukan. Ungkapan terimakasih manusia ini ditujukan kepada agen Cosmic, yang dalam Hindu dikenal sebagai Dewa Dewi. ${ }^{27}$ Berbagai ajaran agama Hindu terhimpun

\footnotetext{
${ }^{24}$ Muhaimin, Perbandingan Praktik Etika Bisnis, Etika Cina dan Pembisnis Lokal, (Yogyakarta: Pustaka Pelajar, 2011)

${ }^{25}$ Lalitha Parameshwari, "Religious Values and Management Ethics" dalam Journal of Social Welfare and Management, Vol.5, No.2., (2013), hlm.98

${ }^{26}$ Chandrani Chattopadhyay, "Indian Philosophy adn Business Ethics: A Review" dalam Advances in Management and Applied Economics, Vol.2, No.3, (2012), hlm.114.

${ }^{27}$ S.K. Chakraborty dan D. Chakraborty, "The Economic Function in The Hindu Worldview: Its Perennial Social Relevance" dalam Internasional Journal of Social Economics, Vol.34, No.10, (2007), hlm.720.
}

dalam kitab Veda. Namun, ada beberapa kesulitan dalam memahami ajaran ini karena banyaknya teks-teks keagamaan yang telah terlupakan. Seperti misalnya koleksi lebih dari seribu himne untuk Dewa Indra (Dewa peradaban, perang, dan badai) dan Dewa Varuna (Dewa penjaga moralitas). ${ }^{28}$

Dalam filosofi Hindu terdapat konsep Mayavad (bersifat ilusi). Semua hal di dunia adalah ilusi. ${ }^{29}$ Kehidupan dunia adalah cobaan dan ujian untuk membersihkan jiwa manusia. Dalam ajaran Hindu, setiap jiwa manusia hidup memiliki banyak kehidupan. Manusia lahir dan dilahirkan kembali setelahnya dalam raga yang berbeda. kelahiran manusia ini baru berhenti ketika mengalami pembebasan. Bentuk pembebasan itu adalah tidak lahir lagi. Sehingga jika dalam kehidupan manusia tersebut menderita, hal itu adalah hasil perbuatannya di kehidupan yang lalu. Setiap tindakan moral akan mendapatkan imbalan yang sesuai; jika tidak dalam hidup ini, maka dalam kehidapan mendatang. ${ }^{30}$

28 Lalitha Parameshwari, "Religious Values and Management Ethics" dalam Journal of Social Welfare and Management, Vol.5, No.2., (2013), hlm.95

${ }^{29}$ S.K. Chakraborty dan D. Chakraborty, "The Economic Function in The Hindu Worldview: Its Perennial Social Relevance" dalam Internasional Journal of Social Economics, Vol.34, No.10, (2007), hlm.715.

${ }^{30}$ Balvir Talwar dan A.K. Sharma, "Business Excellence Enshrined in Vedic (Hindu) Philosophy", dalam Singapore Management Review, Vol. 26, No.1, (2004), Hlm.7 
Dalam ajaran Hindu terdapat empat tujuan hidup manusia yaitu: ${ }^{31}$

a. Dharma (D); Kejujuran, kebenaran, moralitas, etika, dll

b. Artha (A); Mengejar kekayaan atau uang.

c. Kama

Pemenuhan

keinginan/hasrat yang ada didiri

d. Moksha (M); Kebebasan permanen dalam keadaan kesadaran abadi dan kebahagiaan.

Dari empat tujuan hidup DM (Dharma, Moksha) dianggap menjadi dasar dan puncak, masing-masing. AK (Artha, Kama) adalah berada di level tengah dalam struktur kehidupan sosial (grihastha). Kasta Waisya dan kasta Sudra biasanya yang melakukan Artha dan Kama. Dalam filsafat Hindu, setiap orang harus melakukan kebajikan karena dengan melakukan hal tersebut manusia akan menerima imbalan berkali-kali lipat. Imbalan tersebut dapat menjadi bekal untuk kehidupannya dikelahiran mendatang. Manusia diajarkan untuk tidak menimbun kekayaan dan harus bijaksana dalam memperlakukan uang. ${ }^{32}$ Manusia melakukan pekerjaan sebagai

\footnotetext{
${ }^{31}$ S.K. Chakraborty dan D. Chakraborty,
}

"The Economic Function in The Hindu Worldview: Its Perennial Social Relevance" dalam Internasional Journal of Social Economics, Vol.34, No.10, (2007), hlm.717.

32 Manoj K. Sharma, dkk, "Hindu Philosophy: Bridging Corporate Governance and CSR" dalam Management of enviromental Quality: An Internasional Journal, Vol.20, No.3, (2009), hlm.300. bentuk ibadah kepada Dewa. Melayani pelanggan disamakan dengan melayani Tuhan. Dalam kitab Veda juga dijelaskan bahwa manusia harus bekerja keras selama 100 tahun atau sepanjang hidupnya. ${ }^{33}$

Manusia dapat melakukan bisnis apapun asalkan memegang teguh etika (dharma) Hindu yang terdiri dari kebenaran, kebaikan, ketenangan, dan tidak menyakiti. ${ }^{34}$ Selain itu manusia dianjurkan untuk berkontribusi bagi manusia lainnya. Dalam Veda, kitab agama Hindu, disebutkan bahwa manusia dapat saja hidup sendiri namun ia akan survive jika melakukan usaha bersama. Dalam Hindu dikenal prinsip Samastha Janaanaam sukhino Bhavantu (kesejahteraan maksimum bagi sebagian besar anggota masyarakat). ${ }^{35}$ Jika dilihat dari prinsip tersebut, ajaran Hindu lebih banyak menerapkan sistem etika Utilitarianisme, dimana suatu keputusan usaha yang baik adalah jika memberikan nilai manfaat bagi sebagian besar anggota masyarakat.

33 Balvir Talwar dan A.K. Sharma, "Business Excellence Enshrined in Vedic (Hindu) Philosophy", dalam Singapore Management Review, Vol. 26, No.1, (2004), Hlm.8.

34 Chandrani Chattopadhyay, "Indian Philosophy adn Business Ethics: A Review" dalam Advances in Management and Applied Economics, Vol.2, No.3, (2012), hlm. 118.

${ }_{35}$ Manoj K. Sharma, dkk, "Hindu Philosophy: Bridging Corporate Governance and CSR" dalam Management of enviromental Quality: An Internasional Journal, Vol.20, No.3, (2009), hlm.301 


\section{METODOLOGI PENELITIAN}

Paper ini merupakan penelitian berdasarkan studi konseptual. Hanya data sekunder yang digunakan dalam paper ini, berupa: Al-Quran, buku-buku, journaljournal, serta bahan tulisan yang terkait dengan tema ini.

\section{HASIL DAN PEMBAHASAN}

Sebelum membahas mengenai etika bisnis Islam, saya akan memaparkan terlebih dahulu mengenai Ekonomi Islam. Hal tersebut saya lakukan karena etika bisnis merupakan bagian dari sebuah sistem ekonomi. Etika bisnis merupakan turunan dari sistem ekonomi itu sendiri. Ekonomi Islam adalah ilmu yang mempelajari tentang ekonomi yang sesuai dengan prinsip syariah. Tujuan utama dalam ekonomi adalah untuk mencapai falah melalui suatu tata kelola kehidupan yang baik dan terhormat. Falah secara harfiah diartikan sebagai kemenangan, keberhasilan dan kesuksesan di dunia dan akhirat.

Dalam konteks ekonomi, tujuan falah dijabarkan ke dalam beberapa tujuan, diantaranya: 1) mewujudkan kemaslahatan umat; 2) mewujudkan keadilan dan pemerataan pendapatan; 3) membangun peradaban yang luhur; 4) menciptakan kehidupan yang seimbang dan harmonis. ${ }^{36}$ Tujuan Ekonomi Islam untuk mencapai

\footnotetext{
${ }^{36}$ P3EI, Ekonomi Islam, ( Jakarta: PT RajaGrafindo, 2008),
}

falah ini tentu berbeda jika dibandingkan dengan apa yang diajarkan dalam ajaran Buddha, Hindu dan Kristen. Dalam ajaran Kristen, setiap manusia akan masuk surga karena telah ditebus dosanya dengan pensaliban Yesus. Dalam ajaran Hindu dan Buddha, ada paham mengenai reinkarnasi yaitu sebuah konsep bahwa manusia memiliki banyak kehidupan. Manusia memiliki kehidupan sebelum dan kelahiran setelahnya dan hal tersebut terjadi berulangulang hingga mencapai pembebasan atau nirvana. Dalam konsep Islam, manusia hanya hidup satu kali dan karenanya manusia harus memanfaatkan sebaik mungkin kesempatan tersebut karena apa yang diperbuat manusia di dunia akan diminta pertanggungjawabannya diakhirat kelak, sebagaimana firman Allah:

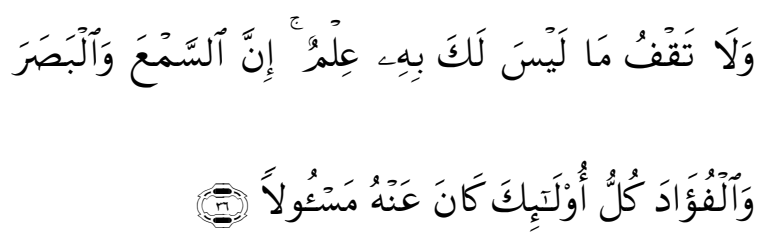

"dan janganlah kamu mengikuti apa yang kamu tidak mempunyai pengetahuan tentangnya. Sesungguhnya pendengaran, penglihatan dan hati, semuanya itu akan diminta pertanggungan jawabnya”. (QS. Al-Isra:36)

Kajian ekonomi Islam mulai memasuki dunia akademis dan kalangan pemerintah pada abad ke-20. Kajian ini 
semakin intens setelah diadakan Muktamar Internasional tentang Ekonomi Islam disponsori oleh Universitas King Abd AlAziz di Jeddah tahun $1976 .{ }^{37}$ Mulai saat itu, para pemikir Islam berupaya mempostulatkan segala hal yang berkaitan dengan penguatan pondasi ekonomi Islam diantaranya metodologi, worldview, body of knowladge, dan teori-teori ekonomi terkait.

Dalam hal metodologi, Zarqa telah merumuskan konsep dan metodologi Ekonomi Islam agar diakui sebagai sebuah Ilmu pengetahuan. Ada tiga eleman utama ilmu pengetahuan diantaranya:
a. Anggapan awal.
b. Nilai-nilai normatif yang berlaku.
c. Bagian deskriptif dari ilmu pengetahuan berupa fakta, asumsi dan teori umum yang berhubungan dengan subjek ilmu pengetahuan yang diteliti.

Zarqa menggunakan diagram dibawah ini untuk menjelaskan hubungan antara ekonomi dan Islam.

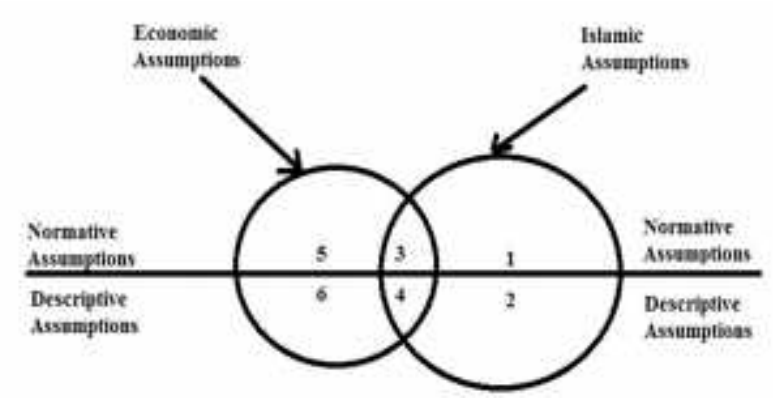

Gambar 1. Diagram Hubungan antara Islam dan Ekonomi (Zarqa, 2003)

${ }^{37}$ Rozalinda, Ekonomi Islam: Teori dan Aplikasinya pada Aktivitas Ekonomi, (Jakarta: Rajawali Press,2014),
Nomor 1 merupakan asumsi normatif secara Islam; contohnya adalah larangan berbuat sombong dalam QS. Luqman:18. Nomor 2 merupakan asumsi deskriptif secara Islam; contohnya adalah QS. An-Nahl:69. Ayat ini menjelaskan bahwa penggunaan madu dapat menyembuhkan penyakit yang sesuai pula dengan ilmu pengobatan saat ini. Nomor 3 merupakan asumsi normatif yang sesuai dengan kaidah Islam maupun ilmu ekonomi; contohnya pelarangan riba dalam QS. AL-Baqarah:278 memiliki persamaan dengan perspektif ilmu ekonomi modern yang juga bahwa riba/bunga dapat mengurangi produktifitas. Nomor 4 merupakan asumsi deskriptif Islami yang sesuai dengan ilmu ekonomi; contohnya QS. Ali Imran:15-16 yang menjelaskan kecintaan manusia terhadap harta, hal tersebut juga terdapat dalam ilmu ekonomi yang menyatakan bahwa keinginan manusia terhadap harta tidak terbatas. Nomor 5 merupakan asumsi ekonomi normatif yang tidak terdapat dalam syariah Islam; contohnya adalah dalam ekonomi konvensional seseorang memiliki harta tanpa batasan, namun di dalam Islam kepemilikan harta dibatasi oleh kehalalan sumber harta tersebut. Nomor 6 merupakan asumsi deskriptif dalam ekonomi; contohnya nilai mata uang kertas tidak 
tergantung pada jumlah emas yang dimiliki negara. ${ }^{38}$

Dari diagram diatas dapat disimpulkan bahwa: pertama, agama Islam merupakan agama yang penuh dengan panduan hidup sehingga memberikan banyak pernyataan normatif dan beberapa pernyataan deskriptif. Kedua, ada hubungan yang menarik pada nomor 3 dan 4. Pada area 3 dan 4 lah dapat dikembangkan ilmu ekonomi Islam serta ditambahkan dengan nomor 6 pada posisi yang netral. Untuk membangun ilmu Ekonomi Islam yang kuat dan mapan diperlukan suatu proses 'pencarian' yang berangkat dari nilai filosofi awal. Saya menggambarkan proses ini dengan menggunakan Piramida Ekonomi Islam, seperti yang tergambar dibawah ini:

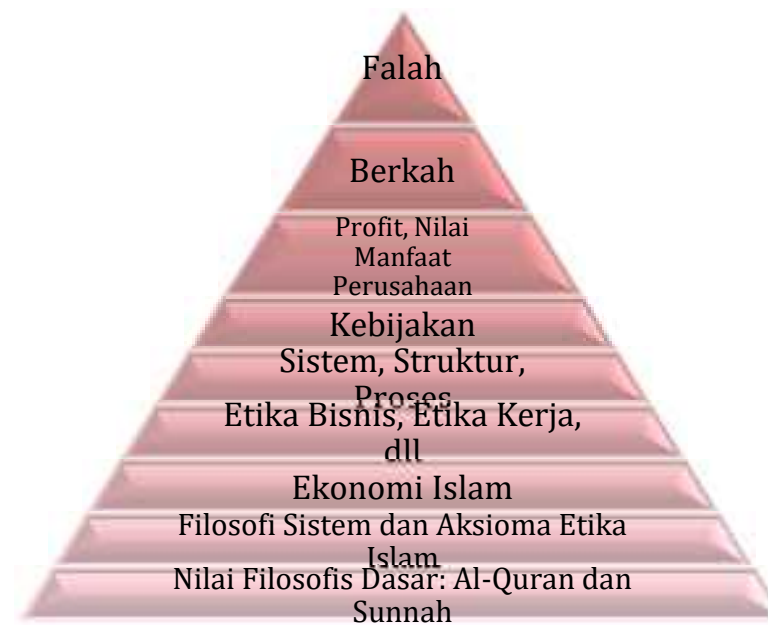

Gambar 2. Piramida Ekonomi Islam

\footnotetext{
${ }^{38}$ Muhammad Anas Zarqa, "Islamization of Economics: The Concept and Methodology", dalam J.KAU: Islamic Econ, Vol.16., No.1, (2003), hlm.342.
}

Piramida ini menggambarkan bahwa nilai filosofis dasar ekonomi Islam adalah Al-Quran dan As-Sunnah. Perlu disadari sejak awal bahwa manusia diciptakan oleh Allah SWT untuk mengabdi dan beribadah kepada-Nya. Dalam pandangan Islam, manusia diciptakan oleh Allah untuk menyembah kepada Allah. Setiap manusia harus berlaku sesuai dengan tuntunan Islam karena Allah melihat segala yang diperbuat oleh manusia sebagaimana yang disebutkan dalam QS. Qaaf:16: “dan Sesungguhnya Kami telah menciptakan manusia dan mengetahui apa yang dibisikkan oleh hatinya, dan Kami lebih dekat kepadanya daripada urat lehernya”. Allah sebagai khalik (Maha subjek) dan manusia sebagai makhluk (objek). Allah menciptakan dunia dan seisinya, baik itu hewan; tumbuhan; manusia; air; api; tanah; bebatuan; dan semua hal yang terlihat maupun tak terlihat. Kemudian Allah menjadikan manusia sebagai khalifah atau wakil Allah di dunia ini. Atau dengan kata lain Allah sebagai Maha subjek mensubjekan manusia yang awalnya hanyalah objek. Manusia kemudian memiliki hak untuk hidup dan memanfaatkan dunia dan seisinya untuk kelangsungan hidup manusia. Dunia dan seisinya ini adalah cobaan dan cara Allah menilai bagaimana manusia memanfaatkan kehidupannya. Untuk menjalani kehidupan sesuai dengan perintah Allah, maka Allah 
memberikan pedoman berupa Al-Quran dan mengutus Nabi-Nabi. Semua hal yang manusia perbuat didunia akan dimintai pertanggungjawabannya diakhirat.

Untuk memenuhi kebutuhannya didunia, manusia melakukan kegiatan ekonomi atau melakukan transaksi bisnis. Dalam pandangan Islam, segala kegiatan yang dilakukan manusia dinilai ibadah oleh Allah tergantung dari niat dan perbuatannya, termasuk dalam hal berbisnis. Dalam melakukan kegiatan bisnis, manusia harus berdasarkan pada AlQuran dan Sunnah. Sehingga dibutuhkan suatu sistem ekonomi Islam yang komprehensif mencakup keseluruhan aturan ekonomi. Sistem ekonomi yang komrehensif membahas tentang teori-teori seperti produksi, konsumsi, distribusi, monopoli harga, campur tangan pemerintah dalam ekonomi, jaminan sosial, sistem fiskal serta diperlukan pula suatu rangkaian etika untuk menjalani bisnis.

Konsep etika dalam Islam telah dikenal dengan nama yang berbeda. Didalam Al-Quran, etika dekat maknanya dengan khuluk. Selain itu, al-Quran juga menggunakan sejumlah istilah yang menjelaskan konsep kebaikan yaitu khair (kebaikan), birr (kebajikan), qist (kewajaran), 'adl (adil, keseimbangan), haqq (kebenaran), ma'ruf (diketahui dan diterima ,dan taqwa (kesalehan). ${ }^{39}$ Etika seringkali dibahas berdekatan dengan 'moral' dan 'akhlak'. Ketiga istilah itu sama-sama menentukan nilai baik dan buruk dari sikap dan perbuatan manusia. Perbedaannya terletak pada standar masingmasing. Akhlak standarnya adalah AlQuran, sedangkan etika standarnya pertimbangan akal pikiran dan moral standarnya adalah adat istiadat kebiasaan yang berlaku di tengah masyarakat. Adapun etika bisnis adalah serangkaian pertimbangan keputusan yang diambil ketika menjalankan sebuah bisnis.

Sebuah etika berangkat dari sistem etika serta aksioma-aksioma yang membantu menjelaskannya. Menurut Beekun Sistem etika Islam memiliki pendekatan sendiri yang berbeda dari berbagai pendekatan sistem etika kontemporer yang ada. Ada beberapa parameter dasar sistem etika Islam yang dapat diungkap dan iktisarkan: ${ }^{40}$

a. Tindakan dan keputusan dinilai etis, tergantung pada maksud (tujuan) individu. Tuhan maha mengetahui, karena itu Tuhan mengetahui maksud manusia secara sempurna.

b. Maksud baik yang diikuti tindakan baik dianggap sebagai ibadah (pengabdian).

${ }^{39}$ Rafik Issa Beekun, Islamic Business Ethics..., hlm.2

${ }^{40}$ Rafik Issa Beekun, Islamic Business Ethics...,hlm.19-20. 
Maksud halal tidak dapat merubah tindakan haram menjadi halal.

c. Islam memberikan kebebasan kepada individu untuk menyakini dan bertindak apa pun yang diinginkan, namun tanpa mengorbankan keadilan dan tanggungjawab.

d. Iman kepada Allah memberikan individu kebebasan sempurna dari sesuatu atau seseorang.

e. Keputusan yang menguntungkan mayoritas atau minoritas bukan ukuran etis tidaknya suatu tindakan. Etika bukan persolan jumlah.

f. Islam menggunakan pendekatan sistem etika terbuka terhadap etika, tidak tertutup dan berorientasi pada diri sendiri (self-oriented).

g. Keputusan etis didasarkan pada pemahaman terhadapa Al-Quran dan alam semesta secara bersamaan.

h. Berbeda dengan sistem etika yang dibangun oleh kebanyakan agama lain, Islam menganjurkan umat manusia untuk mengamalkan tazkiyah melalui partisipasi aktif dalam kehidupan dunia.

Bertentangan dengam seluruh pendekatan sistem etika sekuler, sistem etika Islam tidak bersifat fragmental (terpenggal-penggal) maupun unidimensional akan tetapi sistem ini merupakan bagian tak terpisahkan dari pandangan hidup Islami. Karena itu, sistem etika Islam bersifat sempurna. Dalam kaidah perilaku individu, terdapat keajegan batin (internal consistency) atau 'adl (equilibrium). Aksioma equilibrium (keseimbangan) ini merupakan ini dari surat Al-Baqarah: 143:

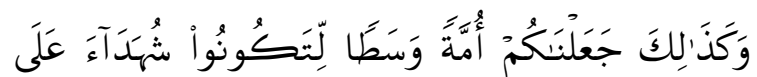

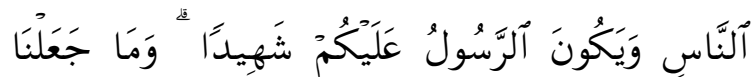

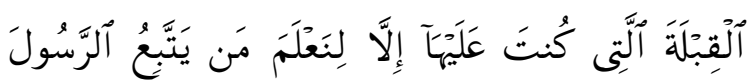

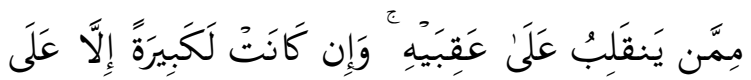

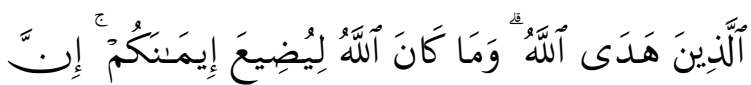

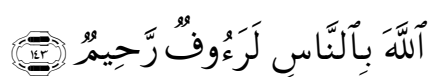

"dan demikian (pula) Kami telah menjadikan kamu (umat Islam), umat yang adil dan pilihan agar kamu menjadi saksi atas (perbuatan) manusia dan agar Rasul (Muhammad) menjadi saksi atas (perbuatan) kamu. dan Kami tidak menetapkan kiblat yang menjadi kiblatmu (sekarang) melainkan agar Kami mengetahui (supaya nyata) siapa yang mengikuti Rasul dan siapa yang membelot. dan sungguh (pemindahan kiblat) itu terasa Amat berat, kecuali bagi orang-orang yang telah diberi petunjuk oleh Allah; dan Allah tidak akan menyia-nyiakan imanmu. Sesungguhnya Allah Maha Pengasih lagi Maha Penyayang kepada manusia”. 
Adapun untuk mengembangkan sistem etika Islam lebih jauh, perlu digali berbagai aksioma-aksioma yang memberi pedoman dalam filsafat etika Islam. Aksioma-aksioma tersebut, diantaranya Kesatuan (unitas), Keseimbangan, Kehendak Bebas, Tanggungjawab, dan Ihsan. ${ }^{41}$ Dari sistem dan aksioma-aksioma etika Islam tersebut maka akan lahir sebuah etika bisnis Islam, etika kerja Islam, dan lain-lain. Etika bisnis dan etika kerja ini akan mempengaruhi perusahaan dan menjadi bahan pertimbangan perusahaan untuk mengambil keputusan bisnis perusahaan. Keputusan bisnis tersebut bertujuan akhir untuk mencapai falah. Uang atau profit atau laba dianggap sesuatu yang penting dalam Islam. Keuntungan merupakan sebuah hal yang alama dan natural. Namun, keuntungan dan laba adalah alat untuk mencapai falah dan bukan merupakan tujuan utama. Hal tersebut berbeda dengan ekonomi kapitalisme yang menjadikan laba sebagai tujuan utama.

Dalam organisasi bisnis atau perusahaan, ada beberapa cara untuk menurunkan etika bisnis Islam ini agar memiliki legitimasi dalam kegiatan bisnis. Salah satunya adalah dengan membuat code of ethic perusahaan. Saya membuat piramida terbalik seperti dibawah ini untuk

41 Rafik Issa Beekun, Islamic Business Ethics...,hlm. 20-29. menggambarkan alur sumber dari code of ethic perusahaan.

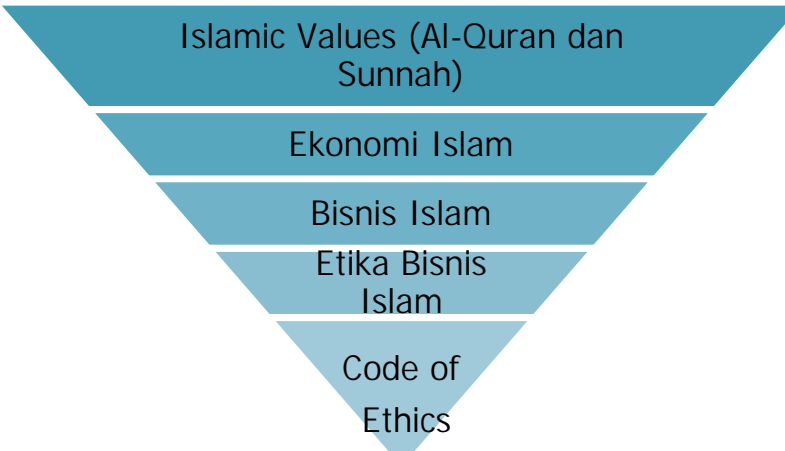

Gambar 3. Alur code of ethic perusahaan

Etika bisnis Islam sebagaimana digambarkan dalm piramida terbalik diatas, bersumber dari nilai Islam tertinggi yaitu Al-Quran dan Sunnah kemudian diturunkan kedalam sebuah postulat ekonomi Islam. Didalam ekonomi Islam sendiri memiliki cabang ilmu yaitu bisnis Islam yang didalamnya juga membahas mengenai etika bisnis Islam. Jika dalam perusahaan ini akan terlihat dalam code of ethic dalam perusahaan dalam bentuk SOP (Standar Operasional Perusahaan). Sedangkan bentuk personal, etika bisnis ini diserap oleh masing-masing pedagang maupun marketer yang bersumber dari ajaran AlQuran dan Sunnah. Penelitian tentang etika Islam dan cabang-cabangnya seperti etika bisnis Islam, etika kerja Islam, etika marketing Islam, dan lain sebagainya telah dan masih terus diteliti dan dikaji oleh para pemikir ekonomi Islam. Penelitian yang terus menerus dan berkualitas diharapkan 
pada akhirnya akan berkontribusi dalam penyempurnaan ilmu ekonomi Islam .

\section{KESIMPULAN}

Dalam paper ini dijelaskan untuk membangun sebuah etika bisnis Islam harus dimulai dari menentukan nilai filosofi dasar. Dalam etika bisnis Islam, filosofi dasar etika bisnis Islam yaitu Al-Quran dan Sunnah. Etika bisnis Islam dibentuk berdasarkan sistem etika Islam dengan menggunakan aksioma-aksioma etika Islam. Untuk membumikan sistem ini, dapat berbentuk code of ethic yang akan mempengaruhi proses didalam sebuah perusahaan. Code of ethic ini akan mempengaruhi corporate governance perusahaan dan sistem produksi, konsumsi dan pemasarannya. Dengan demikian seluruh proses bisnis dapat sesuai dengan Al-Quran.

Etika bisnis Islam berasal dari Alquran dan hadis merupakan bagian yang tidak terpisahkan dan menjadi satu kesatuan dengan etika dalam berprilaku secara umum. Dalam Al-Quran Al-Maidah: 3 Allah menyebutkan bahwa: “...Pada hari ini telah Kusempurnakan untuk kamu agaтати, dan telah Ku-cukupkan kepadamu nikmat-Ku, dan telah Ku-ridhai Islam itu Jadi agama bagimu. Maka barang siapa terpaksa karena kelaparan tanpa sengaja berbuat dosa, Sesungguhnya Allah
Maha Pengampun lagi Maha Penyayang”. Dalam ayat ini bisa dilihat bahwa Islam merupakan agama yang sempurna. Islam merupakan the way of life yang mencakup semua aspek kehidupan. Islam bukanlah agama yang baru, Islam merupakan agama yang telah ada sejak 4000tahun yang lalu, yang memiliki sumber ajaran yg sama dengan yang dibawa oleh Nabi Ibrahim, yang kenabiannya diakui oleh berbagai agama seperti Kristen, Yahudi, Zoroaster, Pagan, dst. Sekitar 3/4 manusia beragama didunia ini mengakui keberadaan nabi Ibrahim, dan memiliki sumber yang sama. ${ }^{42}$ Jadi, Islam sebagai agama yang telah disempurnakan oleh Allah sebenarnya dapat menjadi panduan etika untuk seluruh umat manusia, tidak hanya muslim namun juga non muslim. Pemikiran sekuler hanya menggambil prinsip dan nilai-nilai yang menguntungkan tersebut dapat kita perbaiki dengan mendorong tumbuhnya pemikiran yang berdasar pada Al-Quran dan Hadis yang kemudian diharapkan dapat membentuk tatanan sosial yang lebih baik. Salah satu bentuk pemikiran itu dapat berupa pemikiran etika bisnis Islami ini yang merupakan salah satu 'turunan' dari Al-Quran dan Sunnah yang dapat

${ }^{42}$ M. Hashim, "Islamic Perception of Business Ethics and the Impact of Secular Thoughts on Islamic Business Ethics", dalam Internasional Journal of Academic Research in Business and Social Sciences, Vol.2, No.3.,(2012), hlm.98-120. 
digunakan secara praktis oleh praktisi bisnis.

\section{DAFTAR PUSTAKA}

Azmi, Sabahuddin. "An Islamic Approach to Business Ethics", dalam Renaissance: A Monthly Islamic Journal Pakistan, Vol.15, Issue.5, (2005).

Barnhart, Michael G. "Theory and Comparison in the Discussion of Buddhist Ethics" dalam Philosophy East and West, Vol.62, No.1, (2012).

Beekun, Rafik Issa. Islamic Business Ethics. Virginia: Internasional Institute of Islamic Thought, 1997.

Bertens, K. Pengantar Etika Bisnis. Yogyakarta: Kanisius, 2000.

Chakraborty, S.K. dan D. Chakraborty, "The Economic Function in The Hindu Worldview: Its Perennial Social Relevance" dalam Internasional Journal of Social Economics, Vol.34, No.10, (2007).

Chattopadhyay, Chandrani. "Indian Philosophy adn Business Ethics: A Review" dalam Advances in Management and Applied Economics, Vol.2, No.3, (2012).

Conelly, Peter Connelly. Aneka Pendekatan Studi Agama. Yogyakarta: Lkis Group, 2002

Desjardins, Joseph. An Introduction to Business Ethics. Singapore: Mc Graw Hill, 2014.

Duffie, Darrell dan Jeremy C. Stein, "Reforming LIBOR and Other Finansial Market Benchmarks", dalam Journal of Economic Perspective, Vol. 29, No.2, (2015)
Gould, Stephen J. "The Buddist Perspective on Business Ethics: Experiental Exercises for Exploration and Practice" dalam Journal of Business Ethics, Vol.14, No.1, (1995).

Hashim, M. "Islamic Perception of Business Ethics and the Impact of Secular Thoughts on Islamic Business Ethics", dalam Internasional Journal of Academic Research in Business and Social Sciences, Vol.2, No.3.,(2012).

Hunt, Shelby D. dan Scott J Vittel, "The General Theory of Marketing Ethics: A Revision and Three Questions", dalam Journal of Macromarketing, Vol.26, (2006).

Johnson, Craig. "Enron's Ethical Collapse: Lessons for Leadership Educator", dalam Journal of Leadership Education, Vol. 2, Issue 1, (2003).

Karim, Rusli. Agama dan Masyarakat Industri Modern. Yogyakarta: Media Widya Mandala, 1992.

Muhaimin. Perbandingan Praktik Etika Bisnis, Etika Cina dan Pembisnis Lokal. Yogyakarta: Pustaka Pelajar, 2011

Nugroho, AA. Dari Etika Bisnis ke Etika Ekobisnis. Jakarta: PT Grasindo, 2001.

Nurhayani, "Upaya Penyelesaian BLBI (Bantuan Likuiditas Bank Indonesia)", dalam Lex Jurnalica, Vol.4, No.1, (2006).

P3EI. Ekonomi Islam. Jakarta: PT RajaGrafindo, 2008.

Pace, Stefano. "Does Religion Affect the Materialism of Consumers? An Emperical Investigation of Buddist Ethics and the Resistance of the Self", 
dalam Journal of Business Ethics, Vol.112, No.1, (2013).

Parameshwari, Lalitha. "Religious Values and Management Ethics" dalam Journal of Social Welfare and Management, Vol.5, No.2., (2013).

Putra, E.D. "Bisnis dan Etika Kristiani" dalam Jurnal Ulumul Quran, tanpa tahun.

Rozalinda. Ekonomi Islam: Teori dan Aplikasinya pada Aktivitas Ekonomi. Jakarta: Rajawali Press,2014.

Sharma, Manoj K., dkk, "Hindu Philosophy: Bridging Corporate Governance and CSR" dalam Management of enviromental Quality: An Internasional Journal, Vol.20, No.3, (2009).

Talwar, Balvir dan A.K. Sharma, "Business Excellence Enshrined in Vedic (Hindu) Philosophy", dalam Singapore Management Review, Vol. 26, No.1, (2004)

Zarqa, Muhammad Anas . "Islamization of Economics: The Concept and Methodology", dalam J.KAU: Islamic Econ,Vol.16., No.1, (2003).

Zsolnai, Laszlo "Western Economics Versus Buddhist Economics" dalam Society and Economy, Vol.29, No.2, (2007). 